Table S4. Number of genes modulated after low and high dose exposures in the mammary glands of $\mathrm{BALB} / \mathrm{c}$ and C57BL/6 at early (top) and late (bottom) timepoints after exposure.

\title{
Early response
}

\begin{tabular}{|c|c|c|c|c|c|c|c|}
\hline Strain & Dose & Regimen & $\begin{array}{l}\text { Criteria for ge } \\
\text { Fold change }\end{array}$ & $\begin{array}{l}\text { e selection } \\
\text { p-value }\end{array}$ & Unique genes & $\begin{array}{c}\text { Up- } \\
\text { regulated }\end{array}$ & $\begin{array}{c}\text { Down- } \\
\text { regulated }\end{array}$ \\
\hline C57BL/6 & 4 x $7.5 \mathrm{cGy}$ & Low & $>0.58$ & $<0.1$ & 78 & 34 & 44 \\
\hline BALB/c & $4 \times 7.5 \mathrm{cGy}$ & Low & $>0.58$ & $<0.1$ & 313 & 146 & 167 \\
\hline C57BL/6 & 4 x 1.8 Gy & High & $>0.58$ & $<0.01$ & 429 & 115 & 314 \\
\hline BALB/c & $4 \times 1.8 \mathrm{~Gy}$ & High & $>0.58$ & $<0.01$ & 658 & 190 & 468 \\
\hline
\end{tabular}

\section{1-Month response}

\begin{tabular}{lccccrrr}
\multicolumn{1}{c}{ Strain } & Dose & Regimen & \multicolumn{2}{c}{ Criteria for gene selection } & Unique genes & $\begin{array}{c}\text { Up- } \\
\text { regulated change }\end{array}$ & $\begin{array}{c}\text { Down- } \\
\text { regulated }\end{array}$ \\
\hline \hline C57BL/6 & $4 \times 7.5$ cGy Low & $>0.58$ & $<0.1$ & 294 & 75 & 219 \\
BALB/c & $4 \times 7.5$ cGy Low & $>0.58$ & $<0.1$ & 242 & 103 & 139 \\
C57BL/6 & $4 \times 1.8$ Gy High & $>0.58$ & $<0.01$ & 380 & 166 & 214 \\
BALB/c & $4 \times 1.8$ Gy High & $>0.58$ & $<0.01$ & 223 & 56 & 167 \\
\hline
\end{tabular}

